\title{
LEARNING TOOL FOR ROBOTICS BASIC PROGRAMMING BASED ON CONTEXTUAL TEACHING AND LEARNING TO IMPROVE PROBLEM-SOLVING SKILLS
}

\author{
M Syariffuddien Zuhrie ${ }^{1}$, Munoto ${ }^{2}$, I G P Asto B ${ }^{3}$, Lilik Anifah ${ }^{4}$ and Nur Hasanah ${ }^{5}$ \\ 1,2,3,4 Universitas Negeri Surabaya, Surabaya, Indonesia. \\ ${ }^{5}$ Computer Science and Software Engineering, Swinburne University of Technology, Australia \\ E-mail: zuhrie@unesa.ac.id
}

\begin{abstract}
In the robotics program design basic course, it is very essential to be able to construct programming and then translate it into the language. If there is a design error in the algorithms and mistakes in the flowchart or an error in translating it into a programming language, the application software would be unable to work. The objectives of this study are to develop the basic teaching module for Robotics Programming and to implement robotics courses oriented on contextual teaching and learning to enhance university students' problem-solving skills. This study was designed with pre-action, action and reports procedures. 4D development was employed in the software development process. Implementation processes cover four phases: identifying, planning, creating, and disseminating. The findings suggested that contextual teaching and learning enable students to be actively engaged in the learning process encourage and motivated more active students' activities and promote creativity.
\end{abstract}

Keywords: contextual teaching and learning, learning tool, robotics basic programming language, problemsolving skills

\section{INTRODUCTION}

The advancement of programming software to assist activities in the business sector is advancing very rapidly, this will have implications, that employees who create and manage application programs in the business sector need to operate as required and as efficient as possible. Particularly if the activities demanded skilled programmers to develop a good programming algorithm for the software requested by the industrial sector then converted it into the programming language for the Robotics Basic Programming courses. In regards, a basic programming language from robotics can be built into a type which is simpler to use [1]

The capability to construct programming algorithms and flowchart and afterward transform into its language for the Robotics Basic programming course can be a very determining factor. If a programming error in the algorithms and flowchart or an error in translating it into programming language occurs would result in the application program that can not be operated [1].
The scenario could lead to delays in the company's service. A programmer who can complete the programming algorithm course and basic robotics-programming course in a unified way is expected to address the challenge [1]. Constructing learning tools for robotics programming basic subjects and combines them with the robotics and programming algorithms courses is essential to solving this problem. Relevant goals to be accomplished in this study is the compilation of the Robotics Basic Programming course teaching module connected with the robotics course focused on contextual teaching and learning to develop student skills which are composed of: (1) the Robotics Basic Programming teaching module integrated with the robotics courses and (2) the Robotics Basic Programming Kit. Through its interactive benefits and appealing presentation, it will provide the freedom to the students and lecturers to uncover each submitted subject deeply and rapidly. This approach would also increase student motivation, curiosity, and ability[1].

The emphasis of the past studies is the model of the system in the field of artificial 
intelligence robotics through the booming firefighter home robot, which will be held annually in the Indonesian Robot Contest and the Industry to accelerate Indonesian robotics world. The robot is currently utilizing advanced technology since the supervision is fully managed as a human replacement by a microprocessor and people are working to improve low-cost technology [2]. The emphasis of the first-year research is a teaching module manufacturing, mechanical design planning, control system by microprocessor innovation and robot maneuverability [2].

Contextual learning is a mechanism where the brain is activated to establish patterns that represent definition. This is an action to stimulate students in self-pumping capacity, as students seek to understand concepts, implement and interact with the real world.

Problem-solving has become a valuable skill required to work in the fields after leaving schools. This is one of the skills that the learning process attempts to develop [3], [4]. A person, who is informed of the problem, is capable of identifying the complexity or source of the dispute which causes the concern situation and is capable of solving the problem by finding the best way to address it. It is thus one of the key teaching targets but is the issue that most students consider difficult [5]-[8].

Regarding contextual learning approach, teaching is not the transfer of knowledge from teacher to student to memorize several concepts that seemed disconnected from everyday life, but with a greater focus on supporting it easier for students to reach for the opportunity to live (life skills) on what they studied [9]. It integrates material using a range of active learning strategies to help students link what they already know to what they are supposed to learn and develop new information from this learning process's analysis and synthesis. The studies showed that contextual learning is beneficial to improve the students' problems solving ability and learning achievement [10][15]. Samo et al. [16] showed contextual learning is better able to increase the problemsolving ability than conventional learning. Furthermore, Hargrove \& Nietfeld [17] suggested that conventional learning should be used more schools as it improves students' problem-solving. Oktora [18] added that the inquiry method contextual learning can increase students' activity and learning achievement.

The stated goal of this study is to write the robotics programming of the basic teaching module and to incorporate robotics courses oriented on contextual teaching and learning to establish the problem-solving skills of the college students.

\section{METHOD}

The software development process employed 4D design. Implementation processes involve four phases: define, design, develop, and disseminate [19]. The four phases of the 4D models are as follows, which is: the object of the definition stage is to create and describe the learning terms. This stage evaluates the learning goals and regulates the content to be learned. The defining stage consists of several analytical stages, namely front-end analysis, learner analysis, analysis of tasks, and analysis of interests. The front-end research is used to assess the main issue of the lecturers' faces. In the final preliminary review, alternative system creation for learning needed to be considered. The analysis of learners is conducted to evaluate students. Identify the features of the students in robotic basic programming as shown in the learning design and development. The task analysis consists of procedures for evaluating the content of learning units, task analysis conducted to describe the scope of the teaching material, including: (1) material structure analysis, (2) analytical methods, (3) information process evaluation, (4) concept analysis and (5) objective derivation. Interest analysis is carried out to assess or formulate learning objectives for the students to accomplish [19]. 
The designing stage is intended to develop a prototype learning system. This includes 3 phases namely: standard reference test planning as a bridge from the defining phase to the designing phase. Criterion reference test translates basic standards into the description of the learning material; the Media determination stage is handled with an overview of the subject matter to assess the relevant media.

The developing stage aims to make a learning system that has been refined based on expert feedback. This process consists of three phases as follows: evaluation of the system by experts followed by a review; small testing, the test results as the criterion for correction; and further testing in the real teaching and learning process. At this stage, the empirical testing modules were carried out on a limited of students from Universitas Negeri Surabaya in the Electrical Engineering Department. The students are attending Robotics Basic Programming courses. The disseminating phase is the phase of implementing the developed device on a large scale and intends to evaluate the feasibility of product development [19]. Figures 1 and 2 demonstrate the research process in cycle I and cycle II respectively.

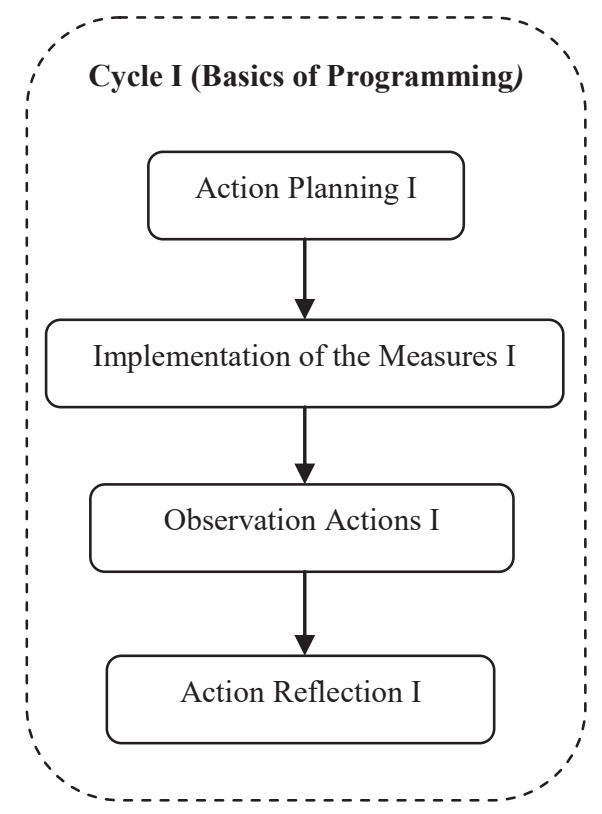

Figure 1. Chart of Research Procedure (Cycle I)

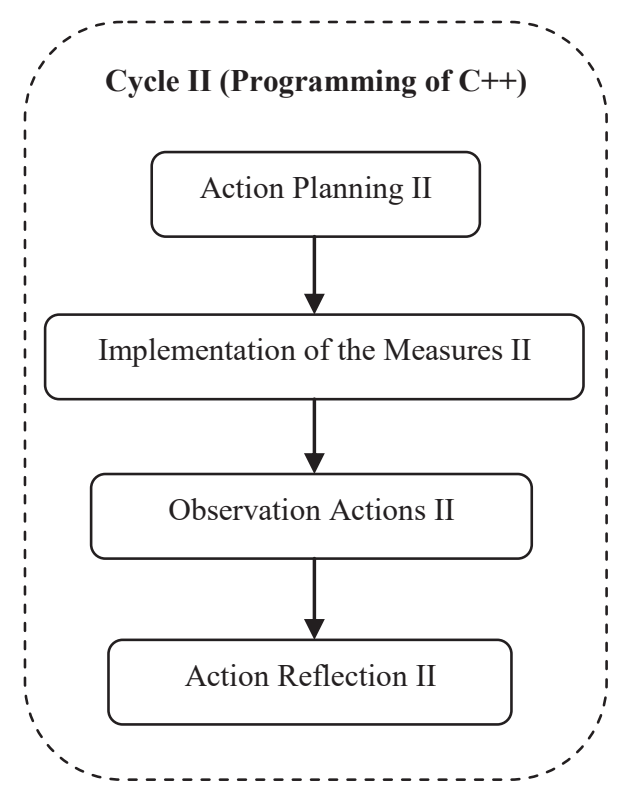

Figure 2. Chart of Research Procedure (Cycle II)

The instruments were verified by experts who consisted of an informatics engineering lecturer as a subject matter expert, an electrical engineering lecturer as a media specialist and one lecturer as a specialist in the Indonesian language. Experts' assessment has been descriptively and qualitatively analyzed. The explanation above offers an example that competencies of students are built in the context of knowledge and skills within the framework of modern education. Student learning outcomes apply science in competency mastery and skills. Knowledge is reviewed as a test method and as a reference framework for ability assessment in performing tasks, in the learning process through evaluation in the form of questions.

\section{RESULTS AND DISCUSSION}

The module validation sheets compose six classifications: features, content, language, illustrations, format and (cover) presentation. The module is accurate if it receives an average score of more than two from the experts. Otherwise, if the score is less than two then the module is invalid. Data review of modul validation features is shown in Table 1. 


\begin{tabular}{|c|c|c|c|c|c|c|}
\hline \multirow{3}{*}{ No. } & \multicolumn{5}{|c|}{ Scores Validation } & \multirow{3}{*}{ Information } \\
\hline & \multicolumn{3}{|c|}{ Expert } & Total & Average & \\
\hline & 1 & 2 & 3 & & & \\
\hline 1. & 3 & 4 & 3 & 10 & 3.333 & valid \\
\hline 2. & 4 & 4 & 4 & 12 & 4.000 & valid \\
\hline 3. & 4 & 4 & 4 & 12 & 4.000 & valid \\
\hline 4. & 3 & 3 & 3 & 9 & 3.000 & valid \\
\hline 5. & 4 & 4 & 4 & 12 & 4.000 & valid \\
\hline \multicolumn{7}{|c|}{ Contents / Material } \\
\hline 6. & 4 & 3 & 4 & 11 & 3.667 & valid \\
\hline 7. & 4 & 3 & 4 & 11 & 3.667 & valid \\
\hline 8. & 4 & 3 & 4 & 11 & 3.667 & valid \\
\hline 9. & 4 & 3 & 4 & 11 & 3.667 & valid \\
\hline 10. & 3 & 3 & 3 & 9 & 3.000 & valid \\
\hline 11. & 3 & 3 & 3 & 9 & 3.000 & valid \\
\hline 12. & 3 & 3 & 3 & 9 & 3.000 & valid \\
\hline 13. & 4 & 4 & 4 & 12 & 4.000 & valid \\
\hline 14. & 3 & 4 & 3 & 10 & 3.333 & valid \\
\hline \multicolumn{7}{|c|}{ Language } \\
\hline 15. & 3 & 4 & 3 & 10 & 3.333 & valid \\
\hline 16. & 3 & 4 & 3 & 10 & 3.333 & valid \\
\hline 17. & 3 & 3 & 3 & 9 & 3.000 & valid \\
\hline \multicolumn{7}{|c|}{ Illustration } \\
\hline 18. & 3 & 3 & 3 & 9 & 3.000 & valid \\
\hline 19. & 3 & 4 & 3 & 10 & 3.333 & valid \\
\hline 20. & 3 & 3 & 3 & 9 & 3.000 & valid \\
\hline \multicolumn{7}{|c|}{ Format } \\
\hline 21. & 3 & 4 & 3 & 10 & 3.333 & valid \\
\hline 22. & 3 & 3 & 3 & 9 & 3.000 & valid \\
\hline 23. & 3 & 4 & 3 & 10 & 3.333 & valid \\
\hline \multicolumn{7}{|c|}{ The appearance/cover } \\
\hline 24. & 4 & 4 & 4 & 12 & 4.000 & valid \\
\hline 25. & 3 & 4 & 3 & 10 & 3.333 & valid \\
\hline
\end{tabular}

The results of the module evaluation determined that the module is valid, based on Table 1. Based on the data it can be stated that the average scores provided by the three validators are more two in the arrangement of the module in terms of characteristics, content or materials, language, illustrations, format, and cover. The learning outcomes obtained after the implementation of the study in both cycles are portrayed in Table 2 .

Table 2. Learning Results of Robotics Basic Programming in Cycle 1

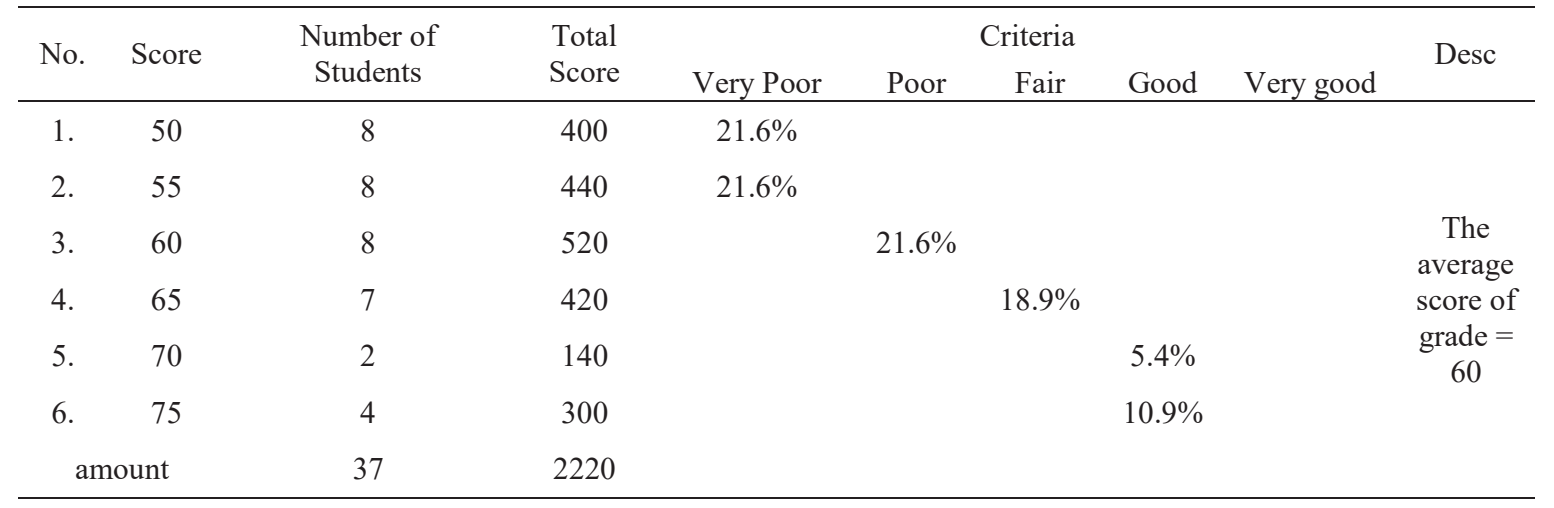

Table 2 demonstrates the average score of the Robotics Basic Programming course at the first cycle is lower than the requirements level (60.00). The percentages of the students who achieved the criteria of very poor, poor, fair; and good are 16 students (43.2\%), 8 students $(21.62 \%), 7$ students (18.9\%), and 6 students $(16.21 \%)$ respectively. 
This proves that students who have already comprehend the Robotics Basic programming materials with contextual teaching and learning strategies are still low with a percentage of $35.2 \%$. The remaining students with a percentage of $64.8 \%$ do not fully comprehend the provided materials, therefore adjustments are still expected to maximize the learning outcomes in the cycle I.

Table 3 depicts the average scores of students' activities in cycle I. The percentages of students who meet the requirements for the criteria of very poor, poor, fair, and good are
$35.1 \% \quad 32.4 \% \quad 24.3 \%$ and $8.2 \%$ respectively. Therefore, the second cycle needs to be reinforced.

After observing the results in the first cycle, an evaluation was performed. In the first cycle, the contextual teaching and learning method is not yet carried out effectively, provided that the mean score of the Robotics Basic Programming course is low at 60.00 ; (2) The lecturer preferred to use the lecturing method thus the learning atmosphere is not oriented to the contextual teaching and learning methods.

Table 3. Average Scores of StudentS' Activities in Cycle I

\begin{tabular}{|c|c|c|c|c|c|c|c|c|c|}
\hline \multirow{2}{*}{ No. } & \multirow{2}{*}{ Score } & \multirow{2}{*}{$\begin{array}{c}\text { Number } \\
\text { of } \\
\text { Students }\end{array}$} & \multirow{2}{*}{$\begin{array}{l}\text { Total } \\
\text { Score }\end{array}$} & \multicolumn{5}{|c|}{ Criteria } & \multirow{2}{*}{ Desc } \\
\hline & & & & Very poor & Poor & Fair & Good & Very good & \\
\hline 1. & 40 & 6 & 240 & $16.2 \%$ & & & \multirow{8}{*}{$\begin{array}{l}8.2 \% \\
8.2 \%\end{array}$} & & \multirow{8}{*}{$\begin{array}{c}\text { The } \\
\text { average } \\
\text { score } \\
\text { class = } \\
52.8\end{array}$} \\
\hline 2. & 45 & 7 & 315 & $18.9 \%$ & & \multirow{6}{*}{$\begin{array}{l}13.5 \% \\
10.8 \%\end{array}$} & & & \\
\hline 3. & 50 & 6 & 300 & & $16.2 \%$ & & & & \\
\hline 4. & 55 & 6 & 330 & & $16.2 \%$ & & & & \\
\hline 5. & 60 & 5 & 300 & & & & & & \\
\hline 6. & 65 & 4 & 260 & & & & & & \\
\hline 7. & 70 & 3 & 210 & & & & & & \\
\hline & bunt & 37 & 1955 & $35.1 \%$ & $32.4 \%$ & $24.3 \%$ & & & \\
\hline
\end{tabular}

Table 4 demonstrates the data from the second cycle. Primarily focused on Table 5, the second cycle course of Average is 80.5 points exceeds the quality in cycle I. The students classified in the criteria of poor, fair, good and very good are $5.40 \%, 2.70 \%, 21.6 \%$, and $41.7 \%$ respectively. This implies that the contextual teaching and learning method adopted in the basic programming course of robotics could raise student performance.

Table 5 shows the average score of students' activity in the second cycle categorized as good and very good criteria are 73.8 and $56.7 \%$ respectively. There is no students with very poor criteria, but the students qualify as fair and poor criteria are 2 and 7 respectively. This suggests that CTL is in harmony with the expectations and preferences of students in electrical engineering who are enthusiastic and engaged but less self-assured.

Reflection in the cycle II resulted in (1) Contextual Teaching and Learning enhanced learning outcomes that achieved the score of 80.5; and (2) Students generate innovations and recognize and complete the mission, and present results effectively, as approximately $56.7 \%$.

Table 4. Learning Results of Robotics Basic Programming in Cycle II

\begin{tabular}{|c|c|c|c|c|c|c|c|c|c|}
\hline \multirow{2}{*}{ No. } & \multirow{2}{*}{ Score } & \multirow{2}{*}{ Number of Students } & \multirow{2}{*}{ Total Score } & \multicolumn{5}{|c|}{ Criteria } & \multirow{2}{*}{ Desc } \\
\hline & & & & Very poor & Poor & Fair & Good & Very good & \\
\hline 1. & 55 & 1 & 55 & & $2.7 \%$ & \multirow{5}{*}{$2.7 \%$} & & & \multirow{7}{*}{$\begin{array}{c}\text { The } \\
\text { average } \\
\text { score } \\
\text { class }= \\
80.5\end{array}$} \\
\hline 2. & 60 & 1 & 60 & & $2.7 \%$ & & & & \\
\hline 3. & 65 & 1 & 65 & & & & & & \\
\hline 4. & 70 & 8 & 560 & & & & $21.6 \%$ & & \\
\hline 5. & 80 & 10 & 800 & & & & $28.6 \%$ & & \\
\hline 6. & 90 & 16 & 1440 & & & & & $41.7 \%$ & \\
\hline \multicolumn{2}{|c|}{ amount } & 37 & 2980 & & $5.4 \%$ & $2.7 \%$ & $50.2 \%$ & $41.7 \%$ & \\
\hline
\end{tabular}


Table 5. Average Score of Student Activities in Cycle II

\begin{tabular}{|c|c|c|c|c|c|c|c|c|c|}
\hline No. & Score & $\begin{array}{c}\text { Number of } \\
\text { Students }\end{array}$ & $\begin{array}{l}\text { Total } \\
\text { Score }\end{array}$ & Very Poor & Poor & $\begin{array}{c}\text { Criteria } \\
\text { Fair }\end{array}$ & Good & Very good & Desc \\
\hline 1. & 50 & 2 & 100 & & $6.7 \%$ & & & & \\
\hline 2. & 55 & 1 & 55 & & $3.3 \%$ & & & & The \\
\hline 3. & 65 & 3 & 195 & & & $10 \%$ & & & average \\
\hline 4. & 70 & 7 & 490 & & & & $23.3 \%$ & & score \\
\hline 5. & 75 & 9 & 675 & & & & & $26.7 \%$ & class $=$ \\
\hline 6. & 78 & 8 & 624 & & & & & $16.7 \%$ & 73.8 \\
\hline 7. & 80 & 7 & 560 & & & & & $13.3 \%$ & \\
\hline \multicolumn{2}{|c|}{ amount } & 37 & 2699 & & $10 \%$ & $10 \%$ & $23.3 \%$ & $56.7 \%$ & \\
\hline
\end{tabular}

Table 6 provides a summary of the robotics programming of learning outcomes in cycles I and II. Furthermore, the analysis of student behavior outcomes in cycles I and II are illustrated in Table 7. The comparison learning outcomes of Robotics Basic Programming reported a rise in the average score. in the cycle I with 60.00 to 80.5 in cycle II. This reveals that the use of methods assisted by the contextual teaching and learning media will enhance Robotics Programming learning outcomes. Students are far more involved, innovative, and creative, allowing meaningful learning. Moreover, according to Table 8, the average statistical score of student activity revealed an enhancement, i.e. still 52.8 in the first cycle, to become 73.8 in the second cycle.

Table 6. Learning Outcomes of Robotics Programming in Cycle I and II.

\begin{tabular}{cccc}
\hline No. & Cycles & $\begin{array}{c}\text { The Average } \\
\text { Score of Class }\end{array}$ & Criteria \\
\hline 1. & cycle I & 60 & Less \\
2. & cycle II & 80.5 & Very good \\
\hline
\end{tabular}

Table 7. Students' Activities in Cycle I and II

\begin{tabular}{cccc}
\hline No. & Cycles & $\begin{array}{c}\text { The average } \\
\text { score Activity }\end{array}$ & Criteria \\
\hline 1. & cycle I & 52.8 & Less \\
2. & cycle II & 73.8 & Good \\
\hline
\end{tabular}

\section{CONCLUSION}

Based on the findings of data discussion and analysis, the research should create conclusion as follows: (1) Implementation of CTL can maximize Robotics Basic Programming learning outcomes, (2) This method can encourage students more engaged, innovative and creative thus the classroom atmosphere is more active. The output can be observed from the mean scores of learning results and the mean score of students' learning activity which is low the cycle I and improving in the cycle 2 until it exceeds a good score.

\section{REFERENCES}

[1] Zuhrie, Agung, Kholis, and Haryudo, "Design of Intelligent Robot as a Tool for Teaching Media Based on Computer Interactive Learning and Computer Assisted Learning to Improve the Skill of Learner," in 6th International Conference on Educational, Management, Administration and Leadership (ICEMAL), 2016, pp. 330333.

[2] Zuhrie, Ismet, Asto, and Lilik, "Design of Intelligent Robot as a Tool for Teaching Media Based on Computer Interactive Learning and Computer Assisted Learning to Improve the Skill of University Student," in 4th Consortium of Asia-Pacific Education Universities (CAPEU), 2017.

[3] N. Delima, "A Relationship between Problem Solving Ability and Students' Mathematical Thinking," J. Math. Educ., vol. 6, no. 1, pp. 21-28, 2017.

[4] S. Saygili, "Examining The Problem Solving Skills and The Strategies Used by High School Students in Solving Non-routine Problem," E-International J. Educ. Res., vol. 8, no. 2, pp. 91-114, 2017.

[5] J. Dostál, "Theory of Problem Solving," Procedia - Soc. Behav. Sci., vol. 174, pp. 2798-2805, Feb. 2015, doi: 10.1016/j.sbspro.2015.01.970.

[6] N. Y. L. Lee and P. N. Johnson-Laird, "Strategic changes in problem solving," 
J. Cogn. Psychol., vol. 25, no. 2, pp. 165-173, Mar. 2013, doi: 10.1080/20445911.2012.719021.

[7] C. K. Ke, "Research on Optimized Problem-Solving Solutions: Selection of the production process," J. Appl. Res. Technol., vol. 11, no. 4, pp. 523-532, Aug. 2013, doi: 10.1016/S16656423(13)71559-1.

[8] M. Lorenzo, "The Development, Implementation, and Evaluation of a Problem Solving Heuristic," Int. J. Sci. Math. Educ., vol. 3, no. 1, pp. 33-58, Mar. 2005, doi: 10.1007/s10763-0048359-7.

[9] E. B. Johnson, Contextual Teaching and Learning, Translatio. Bandung: Mizan, 2012.

[10] N. Nurjamilah, Y. Yerizon, and D. Permana, "The Influence of Contextual Teaching and Learning Model on Students' Mathematical Problem Solving Ability," in Proceedings of the 1st International Conference on Innovation in Education (ICoIE 2018), 2019, doi: 10.2991/icoie-18.2019.93.

[11] E. Suryawati, K. Osman, and T. S. M. Meerah, "The effectiveness of RANGKA contextual teaching and learning on student's problem solving skills and scientific attitude," in Procedia - Social and Behavioral Sciences, 2010, vol. 9, pp. 1717-1721, doi: 10.1016/j.sbspro.2010.12.389.

[12] P. Ekawatiningsih, "Pembelajaran Kontekstual pada Mata Kuliah Restoran untuk Meningkatkan Kompetensi Mahasiswa Pendidikan Teknik Boga," J. Pendidik. Teknol. dan Kejuru., vol. 23, no. 1, p. 67, May 2016, doi: 10.21831/jptk.v23i1.9356.

[13] A. C. Nugraha and D. B. Hertanto, "Upaya Meningkatkan Kualitas Kuliah Teknik Komputasi melalui Pembelajaran Berbasis Contextual Teaching Learning," J. Pendidik. Teknol. dan Kejuru., vol. 22, no. 1, pp. 19-28, 2016, doi: 10.21831/jptk.v22i1.8847.
[14] L. Hariyanto, "Implementasi Project Minerva Model (PMM) dalam Peningkatan Kompetensi Praktik Kerja Batu dan Beton Berbasis Contextual Teaching Learning," J. Pendidik. Teknol. dan Kejuru., vol. 19, no. 2, pp. 235-254, Oct. 2010, doi: 10.21831/jptk.v19i2.7742.

[15] Yusuf, Slamet. P. H., T. Sukardi, and M. Khairudin, "Learning Model Higher Order Thinking Skills at Vocational High School: Achievement and Thinking Behavior International Journal of Advanced Science and Technology," Int. J. Adv. Sci. Technol., vol. 29, no. 7s, pp. 158-170, 2020, Accessed: Apr. 23, 2020. [Online]. Available:

http://sersc.org/journals/index.php/IJAS T/article/view/9424.

[16] D. Dao Samo and B. G. Kartasasmita, "Culture-Based Contextual Learning to Increase Problem-Solving Ability of First Year University Student," J. Math. Educ., vol. 9, no. 1, pp. 81-94, 2018.

[17] R. A. Hargrove and J. L. Nietfeld, "The Impact of Metacognitive Instruction on Creative Problem Solving," J. Exp. Educ., vol. 83, no. 3, pp. 291-318, Jul. 2015 , doi: 10.1080/00220973.2013.876604.

[18] Y. S. Oktora, "Implementasi Pembelajaran Contextual Teaching and Learnig (CTL) Metode Inkuiri untuk Meningkatkan Prestasi Belajar Siswa Kelas X- Penjualan Pada Mata Diklat Membuka Usaha Kecil di SMK PGRI 02 Malang (Studi Pada Siswa Kelas XPenjualan SMK PGRI 02 Malang)," Universitas Negeri Malang, 2009.

[19] S. Thiagarajan, D. S. Semmel, and M. I. Semmel, Instructional Development for Training Teachers of Expectional Children. Minneapolis, Minnesota: Leadership Training Institute/Special Education, University of Minnesota, 1974. 